\title{
DISTRIBUTION AND SOME BIOLOGICAL PARAMETERS OF THE RED GURNARD, CHELIDONICHTHYS CUCULUS (ACTINOPTERYGII, SCORPAENIFORMES, TRIGLIDAE) IN THE NORTH-CENTRAL ADRIATIC SEA
}

\author{
Maria VALLISNERI ${ }^{1 *}$, Stefano TOMMASINI ${ }^{1}$, Marco STAGIONI ${ }^{1,2}$, Chiara MANFREDI ${ }^{1,2}$, \\ Igor ISAJLOVIĆ ${ }^{3}$, and Stefano MONTANINI ${ }^{1,2}$ \\ ${ }^{1}$ University of Bologna, Department of Biological, Geological and Environmental Science, Bologna, Italy \\ ${ }^{2}$ University of Bologna, Laboratory of Marine Biology and Fishery, Fano, Italy \\ ${ }^{3}$ Institute of Oceanography and Fisheries, Split, Croatia
}

\begin{abstract}
Vallisneri M., Tommasini S., Stagioni M., Manfredi C., Isajlović I., Montanini S. 2014. Distribution and some biological parameters of the red gurnard, Chelidonichthys cuculus (Actinopterygii, Scorpaeniformes, Triglidae) in the north-central Adriatic Sea. Acta Ichthyol. Piscat. 44 (3): 173-180.
\end{abstract}

Background. Red gurnard, Chelidonichthys cuculus (Linnaeus, 1758), is distributed in the Mediterranean Sea, Black Sea, and in the eastern Atlantic Ocean from Norway to Mauritania, although it is rarely found in the North Sea and on the Norwegian shelf. The aim of this work was to conduct a comprehensive study of red gurnard in the Adriatic Sea on selected aspects the population biology and some of its environmental implications.

Materials and methods. The sampling covered the entire subdivision GSA17 (north-central Adriatic Sea) and it was based on several bottom trawl surveys of MEDITS and GRUND projects from 2000 through 2009. Biometric parameters, as well as the spatial- and depth distributions were analyzed. The parameters such as the length-weight relation, sex, gonad maturity stage, and the stomach content were determined on a subsample of 539 specimens collected seasonally (summer and autumn-winter) within 2007-2009. The data were processed statistically.

Results. Chelidonichthys cuculus was mainly distributed in the central Adriatic. Juveniles showed a distribution in shallower waters while adults tended to migrate towards the Croatian coast at greater depths. The total length of the fish sampled ranged from 40 to $303 \mathrm{~mm}$ (TL). We assumed the length of $100 \mathrm{~mm}$ as a threshold separating juveniles from adults and the length range of $170-190 \mathrm{~mm}$ as the maturity size for females and males. Isometric- and allometric growth patterns were showed for the juveniles and the adults, respectively. The diet was based almost exclusively on crustaceans (IRI\% > 98\%) and it did not change upon reaching the sexual maturity. Chelidonichthys cuculus should be considered a specialist predator feeding mostly on necto-benthic lophogastrids (IRI\% > 72\%).

Conclusion. This work constitutes an attempt to summarize some environmental and biology aspects of the red gurnard in Adriatic population: differences in depth distribution and growth were found between juveniles and adults but not in diet. Males and females showed differences in growth parameters. Extending the studied area and collecting data of red gurnard in the main areas of production should help in better understanding the biology and dynamics of this species.

Keywords: red gurnard, Aspitrigla cuculus, distribution, biology, north-eastern Mediterranean, diet, growth

\section{INTRODUCTION}

Red gurnard, Chelidonichthys cuculus (Linnaeus, $1758)^{* *}$, is one of the most abundant and commercially important triglid fish species in the Mediterranean Sea and therefore has been included in the list of target species of the MEDITS project (Mediterranean International Trawl Survey) (Bertrand et al. 2002) carried out in the Mediterranean to monitor commercially exploited demersal resources. ICES has identified red gurnard as a new MoU
(Memorandum of understanding) species and has recommended that a survey on its biological data should be conducted in order to define stock characteristics and assist in the development of management strategies for sustainable exploitation (Marriott et al. 2010, Anonymous 2006, 2012).

Red gurnard is a demersal fish species, with a pelagic phase during the early life (Tsimenides et al. 1992, Colloca et al. 1994). The distribution of Chelidonichthys cuculus in the Mediterranean Sea is restricted to the depth range of

\footnotetext{
* Correspondence: Dra. Maria Vallisneri, Dipartimento di Scienze Biologiche, Geologiche e Ambientali, Università di Bologna, Via Selmi 3, 40126 Bologna, Italy, phone: (+39) 051 2094166, fax: (+39) 051 2094286, e-mail: (MV) maria.vallisneri@unibo.it, (ST) stefano.tommasini@unibo.it, (MS) marco.stagioni3@unibo.it, (CM) chiara.manfredi3@unibo.it, (II)igor@izor.hr,(SM)stefano.montanini2@unibo.it.

${ }^{* *}$ Even though some authors have recently referred to this species as Aspitrigla cuculus, the editors decided to follow the nomenclature of FishBase and used Chelidonichthys cuculus as the valid name (Froese and Pauly 2014). According to FishBase the reference for Chelidonichthys cuculus as the accepted senior synonym is Richards and Saksena (1990).
} 
100-220 m (Dieuzeide et al. 1955, Papaconstantinou 1983, Serena et al. 1990, Tsimenides et al. 1992). Juveniles tend to occur in shallower waters than the adults (Serena et al. 1990, Colloca et al. 1994). Due to the missing parts of the time-series data of red gurnard it is difficult to provide a preliminary analytical assessment (Anonymous 2012). Its biology is poorly understood in the Atlantic Ocean (Marriott et al. 2010), and in the northern Mediterranean Sea (Colloca et al. 2003, Vallisneri et al. 2010, 2012). A number of researchers studied the growth of this fish (Baron 1985a, Maisan et al. 1998, Colloca et al. 2003), its length-weight relations (Coull et al. 1989, Mendes et al. 2004, Olim and Borges 2004), reproduction (Baron 1985b), and the diet (Moreno-Amich 1992, Colloca et al. 1994, Terrats et al. 2000). The aim of this study was to analyse the distribution and selected biological traits of the red gurnard population in the north-central Adriatic Sea. Such data are needed for the proper stock assessment.

\section{MATERIALS AND METHODS}

Sampling. The presently reported study was based on the sampling operations of the MEDITS and GRUND projects (summer survey: MEDITS project, Mediterranean International Trawl Survey; winter survey: GRUND project, Gruppo Nazionale Demersali) in the north-central Adriatic Sea (north-eastern Mediterranean) from the Gulf of Trieste to the imaginary line joining the Gargano promontory (Italy) to the borderline between Croatia and Montenegro. The sampling depth distribution ranged from 10 to $500 \mathrm{~m}$. The sampling gear was a bottom trawl made of four panels with the cod-end mesh size of $20 \mathrm{~mm}$ (MEDITS surveys, Fiorentini et al. 1999) and a commercial bottom trawl with the cod-end mesh size of $40 \mathrm{~mm}$ (GRUND surveys). The GRUND project covered Italian territorial waters and international waters while the MEDITS project covered the whole north-central Adriatic Sea, including Croatian territorial waters.

The analysis of the distribution of Chelidonichthys cuculus in terms of areas and depths was performed over the whole north-central Adriatic Sea using MEDITS data from 2000 through 2009, while other biological analyses were performed only on the samples collected from the Italian territorial waters and the international area using both MEDITS and GRUND data from 2007 through 2009. A total of 539 specimens of red gurnard, C. сиси$l u s$, were analysed. The fish captured were frozen on board to prevent digestion of their stomach contents, and finally taken to the laboratory.

Data analyses. Specimens were measured (TL, to the nearest $1 \mathrm{~mm}$ ), weighed ( $W$, to the nearest $0.01 \mathrm{~g}$ ), and dissected. Sex and gonad maturity stages were verified by macroscopic examination of the gonads. The stages of maturation were classified according to Relini et al. (2008). Specimens were classified into two groups: juveniles with $\mathrm{TL} \leq 100 \mathrm{~mm}$ and adults with $\mathrm{TL}>100 \mathrm{~mm}$. The cut-off size to define juveniles was calculated as the first modal component of length-frequency distribution, identified by means of the Battacharya's method (Battacharya 1967), plus standard deviation.
The abundance of Chelidonichthys cuculus was standardized to $1 \mathrm{~km}^{2}$ by using the distance covered and the horizontal opening of the fishing gear. A map with miniature pie charts at the sampling sites was used to represents the geographic distribution of the abundance of both juveniles and adults. The size of the pie charts on the map is proportional to the standardized total abundance of the species. Based on the depth distribution of our data, the studied area was divided into five zones for assessment of the relation between the depth and the fish size (length). Minimum-, maximum-, and mean lengths were calculated by $50-\mathrm{m}$ depth intervals and graphically represented.

Statistical analyses. The chi-squared test was used to compare differences between size classes and depth zones. The non-parametric Kruskal-Wallis test was performed to check differences in the fish depth preferences of juveniles and adult individuals. All the statistical inferences were based on the 0.05 significance level.

We tested both linear and means of non-linear regressions to describe the relation between fish size and fish weight and adopted relations which explained the highest proportion of the variance (highest value of $r^{2}$ ). Length-weight relation was calculated for each size class (juveniles and adults) and sex (females and males) by using the formula:

$$
W=a \mathrm{TL}^{b}
$$

where $W$ is the total weight of the fish [g], TL is the total length [mm], $a$ is the intercept on the Y axis of the regression curve, and $b$ is the regression coefficient. To test for possible significant differences between the estimated $b$-values and $b=3$, the $t$-test was used and 95\% confidence limits (CL) for parameters $b$ were calculated (Froese 2006). Statistical procedures (Shapiro-Wilk test, to check if residuals look normal, and Fligner-Killeen test, to check assumption of homogeneity of variance) followed Zuur et al. (2010).

The maturity stage frequencies by size were computed. In order to estimate the size at which $50 \%$ of individuals were sexually mature, the percentage of mature individuals in 2-cm intervals was calculated for females and males at spawning seasons (from January to June) according to Tsikliras et al. (2010).

Subsamples of 390 stomach contents were taken and preserved in $70 \%$ ethanol solution to prevent further food digestion. Prey items were identified to the lowest possible taxonomic level, counted, and weighed to the nearest $0.1 \mathrm{mg}$ after removal of surface water by blotting paper. The importance of prey categories was evaluated using the percentage frequency of occurrence $(F \%)$, the percentage by number $(N \%)$, and the percentage by weight $(W \%)$. We used these values to calculate the index of relative importance (IRI) (Pinkas et al. 1971):

$$
\mathrm{IRI}=F \% \cdot(N \%+W \%)
$$

as modified by Cortés (1997):

$$
\mathrm{IRI} \%=\left(\mathrm{IRI} \cdot \sum \mathrm{IRI}^{-1}\right) \cdot 100
$$

Prey categories were sorted in decreasing order according to their IRI\%. 
All data analyses were performed with $\mathrm{R}$ software ver. 3.0.2 base (Anonymous 2014).

\section{RESULTS}

Area distribution. Red gurnard, Chelidonichthys сисиlus, occurred in the $26.3 \%$ of trawl samples, through the investigated area, although showing a marked preference for the central Adriatic Sea (Fig. 1). Maximum abundances were recorded in the Croatian territorial waters hauls which showed a mean abundance of 847 individuals per $1 \mathrm{~km}^{2}$ in the positive hauls; mean abundance in the Italian side was 202 individuals per $1 \mathrm{~km}^{2}$ in the positive hauls. Juveniles represented the greatest fraction in the Italian area and in some hauls near the Croatian coast; adults represented the greatest fraction in almost all Croatian hauls.

Depth distribution. A highly significant test results $\left(\chi^{2}\right.$, $P<0.001)$ reflected how strong the size-with-depth at different seasons patterns were.

The species was never sampled 0-50 $\mathrm{m}$ and occasionally between $50-100 \mathrm{~m}$. The red gurnard occurred almost regularly in the depth range of 100-200 $\mathrm{m}$. The distribution of size classes (juveniles and adults) was significantly different (Kruskal-Wallis test, $P<0.001$ ). Juveniles were observed preferentially between $100-150 \mathrm{~m}$ in the Central Adriatic Sea (mean $109 \pm 25.1 \mathrm{~m}$ ), while adults between 100-200 $\mathrm{m}$ down to $250 \mathrm{~m}$ (mean $150 \pm 55.5 \mathrm{~m}$ ) (Figs. 1, 2; Table 1).
Size distribution. Table 2 reports the size range of the specimens classified as juveniles and adults. It also summarizes the data for the two sexes: females ranging from 102 to $303 \mathrm{~mm}$ TL and males from 105 to $277 \mathrm{~mm}$ TL.

Length-weight relations. The non-linear regression model was fitted to the length-weight values by size class (juveniles and adults) and by sexes (females and males) (Figs. 3 and 4). All these relations were highly significant $(P<0.001)$ and were able to explain over $94 \%$ of the variance. About size classes, adults exhibited positive allometric growth $(b=3.266 ; 95 \%$ CL of $b=3.210-3.321$; $b \neq 3 P<0.001)$ while juveniles showed an isometric growth in fact the value of parameter $b(b=3.008 ; 95 \%$ CL of $b=2.892-3.125)$ in the length-weight relation was not statistically different from 3 (t-test, $P>0.001)$. In terms of the sexes, both females and males exhibited a positive allometric growth (for females: $b=3.354 ; 95 \%$ CL of $b=3.246-3.462$ and for males: $b=3.183 ; 95 \% \mathrm{CL}$ of $b=3.100-3.266 ; b \neq 3 P<0.001)$.

Maturity stages distribution by size. The smallest mature males and females of Chelidonichthys cuculus measured around $100 \mathrm{~mm}$. Between 130 and $150 \mathrm{~mm}$ TL a lot of stages were recorded for both sexes highlighting individual variability in gonad maturation. The length at sexual maturity was estimated for both sexes as the total length at which $50 \%$ of the fish were mature (Table 3 ). In fact, over $50 \%$ of the individuals were at stage 3 in the sample taken during the reproductive period (January-June). In both

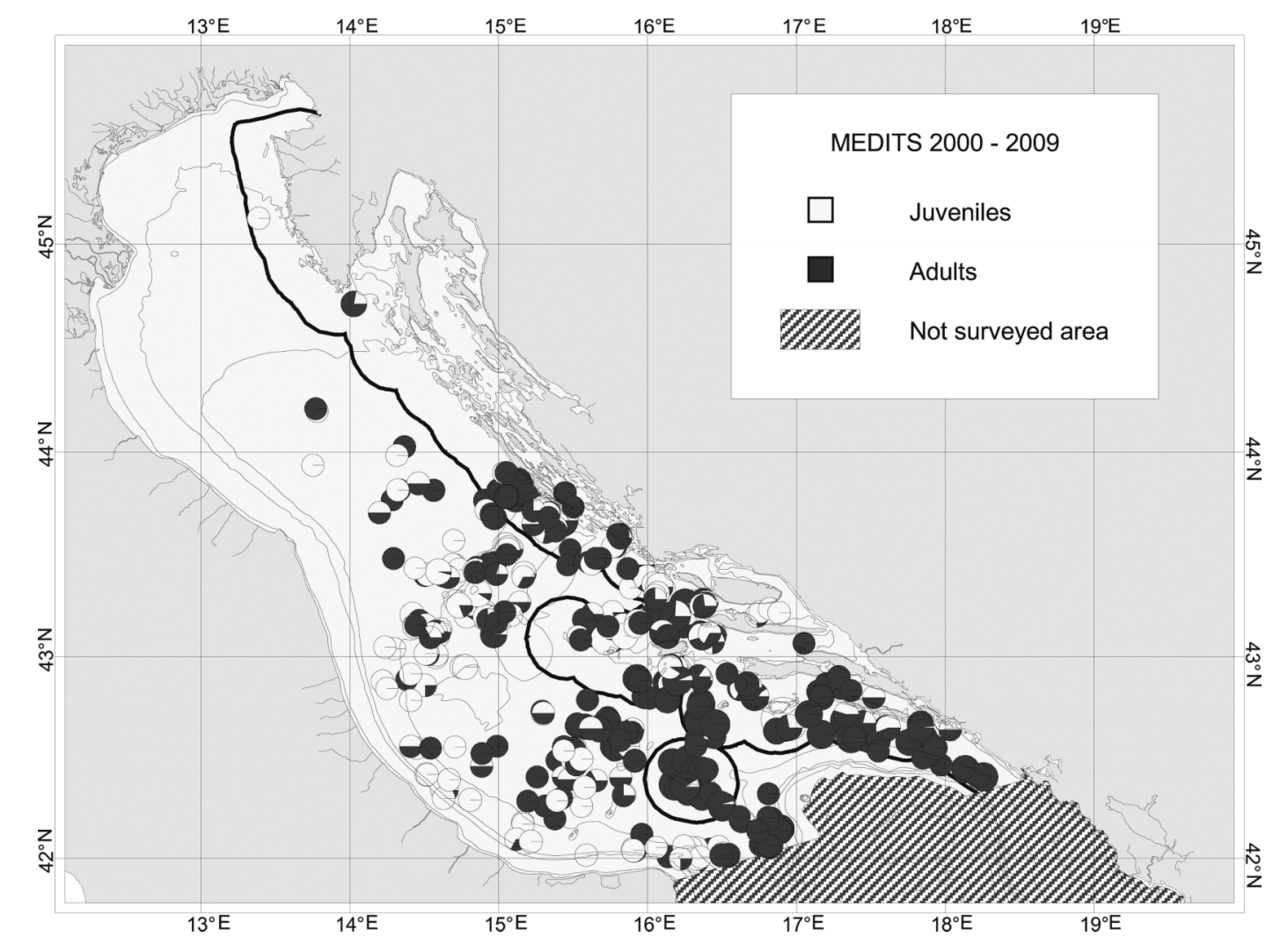

Fig. 1. Map showing the studied area and geographic distribution of the abundance of red gurnard, Chelidonichthys cuculus, in the Adriatic Sea by juveniles and adults (only the successful hauls are shown) 
sexes, some specimens within the 130-170 $\mathrm{mm}$ range had already reached the spawning-ready stage.

Diet. Stomach contents were summarized in Table 4. A total of 17 different food items were found in the diet and classified into five main categories. Almost the entire diet of this species was based on malacostracan crustaceans $(\% N=93.9 ; \% W=91.2 ; \% F=76.9 ; \% \mathrm{IRI}=98.1)$ while teleost fishes, molluscs, and echinoderms were classified as accessory prey. As for the crustaceans, Lophogastrida $(\% N>64 ; \%$ IRI $>70)$ represented the most important prey taxa while Decapoda $(\% N>24 ; \%$ IRI $>18)$ were classified as secondary ones. Lophogaster typicus constituted the basic prey food for both juveniles $(\% N=73.9$; $\%$ IRI $=97.1)$ and adults $(\% N=83.5 ; \%$ IRI $=97.6)$ showing a quite exclusive preference for this species.

\section{DISCUSSION}

Interest in gurnards as commercial species has increased. As a consequence monitoring programmes targeting red gurnard for the stock assessment were recommended by ICES (Anonymous 2012), which should also contribute to a better understanding of the species biology.

Red gurnard, Chelidonichthys cuculus, in the northcentral Adriatic Sea occurred at depths between 50-250 m. It was absent at depths lower than $50 \mathrm{~m}$ preferring the range of 100-200 m, according to the majority of published records. The depth distribution of this fish in the Atlantic was reported as 20 to $250 \mathrm{~m}$ (Wheeler 1969, Anonymous 2006), although with rare occurrences at depths lower than $20 \mathrm{~m}$ and most common presence from 30 to $60 \mathrm{~m}$ (Forest 2001). The juveniles, however, were distributed in more shallow waters than the adult individuals (Serena et al. 1990, Colloca et al. 1994). In the
Mediterranean Sea, red gurnard was reported over a similar depth range as in the Atlantic, with usual depth range of 40 to $300 \mathrm{~m}$ (Tsimenides et al. 1992, Terrats et al. 2000, Colloca et al. 2003, Massutí and Reñones 2005), although they were also recorded as deep as $800 \mathrm{~m}$ off the Cretan shelf (Kallianiotis et al. 2000). Preferred and tolerated temperatures of red gurnard are not known (Marriott et al. 2010) and whether the Atlantic population differs from Mediterranean population, preference for deeper water may be temperature related or linked to the absence of preferred habitat in the shallow inshore water (Ramsay et al. 1998, Rees 2004). Therefore, it will be necessary to

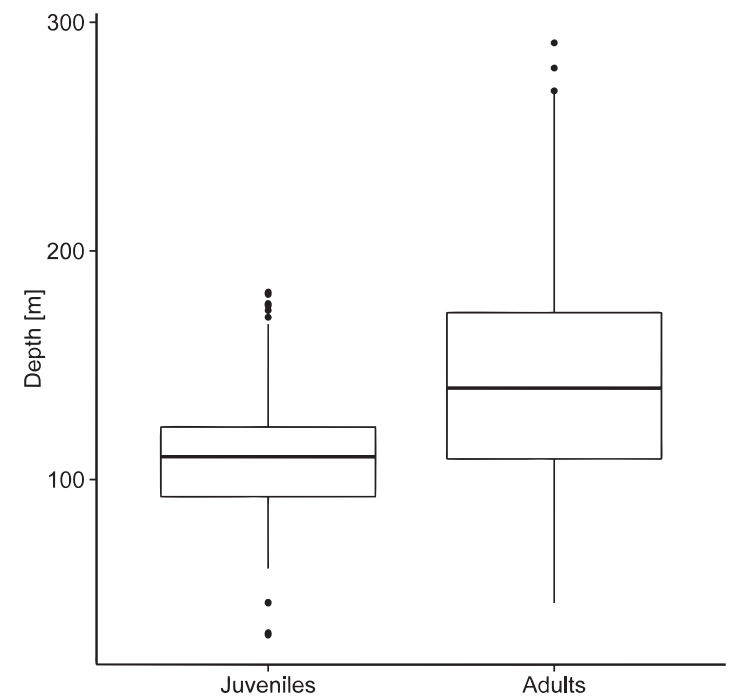

Fig. 2. Boxplot of depth distribution of red gurnard, Chelidonichthys cuculus, from the Adriatic Sea by size classes (MEDITS 2000-2009)

Table 1

Depth distribution of red gurnard, Chelidonichthys cuculus, from the Adriatic sea (MEDITS surveys 2000-2009)

\begin{tabular}{lccccr}
\hline \multirow{2}{*}{ Category } & \multicolumn{5}{c}{ Depth $[\mathrm{m}]$} \\
\cline { 2 - 6 } & $0-50$ & $50-100$ & $100-150$ & $150-200$ & $200-300$ \\
\hline Females & 7 & 294 & 580 & 361 & 297 \\
Males & 7 & 203 & 472 & 272 & 74 \\
Juveniles & 12 & 407 & 1032 & 633 & 500 \\
Adults & 14 & 497 & 1052 & 503 \\
\hline
\end{tabular}

In the depth ranges the start point is exclusive and the end point inclusive.

Total length (TL) and depth range of red gurnard, Chelidonichthys cuculus,

Table 2 from the Adriatic Sea (MEDITS surveys 2000-2009)

\begin{tabular}{|c|c|c|c|c|c|c|}
\hline \multirow{2}{*}{ Category } & \multirow{2}{*}{$n$} & \multicolumn{3}{|c|}{ Total length $[\mathrm{mm}]$} & \multicolumn{2}{|c|}{ Depth $[\mathrm{m}]$} \\
\hline & & Min & Max & Mean \pm SD & Min & $\operatorname{Max}$ \\
\hline Females & 1539 & 102 & 303 & $168.93 \pm 29.26$ & 46 & 291 \\
\hline Males & 1157 & 105 & 277 & $159.80 \pm 22.63$ & 46 & 291 \\
\hline Juveniles & 1525 & 40 & 100 & $81.41 \pm 10.96$ & 32 & 182 \\
\hline Adults & 2696 & 102 & 303 & $165.01 \pm 27.00$ & 46 & 291 \\
\hline
\end{tabular}

$n=$ number of specimens examined, $\mathrm{SD}=$ standard deviation. 


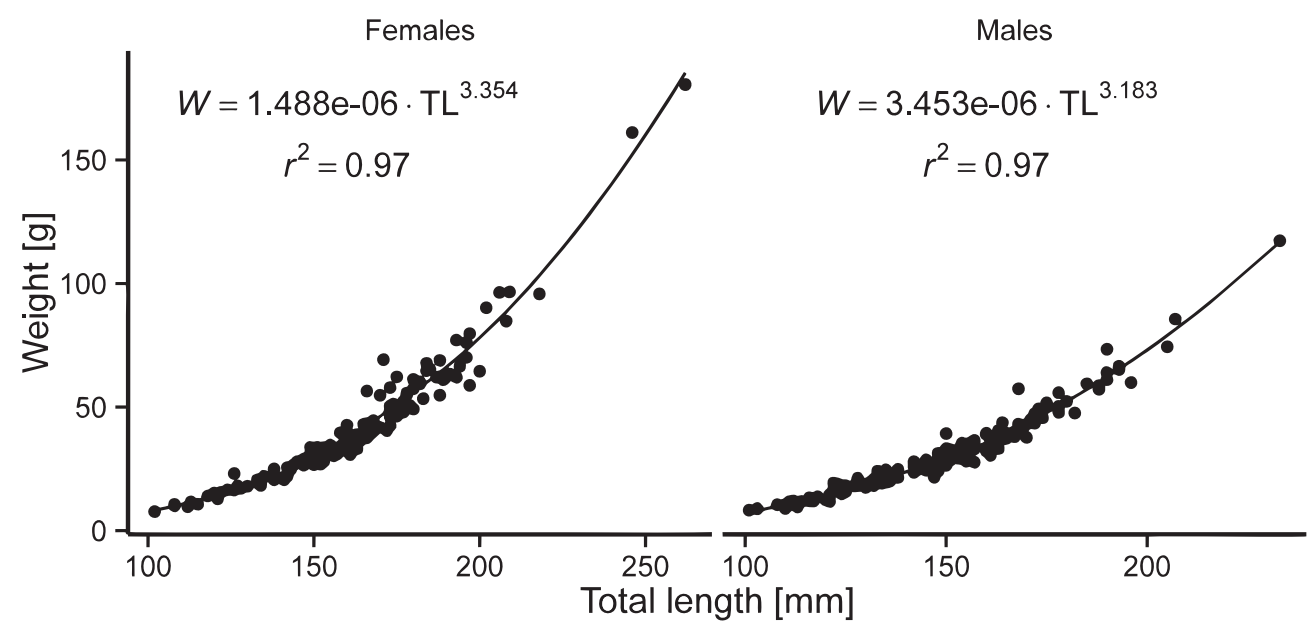

Fig. 3. Length-weight relations for red gurnard, Chelidonichthys cuculus, from the Adriatic Sea: non-linear regression plots for juveniles (left; $n=168$ ) and adults (right; $n=371$ ), respectively

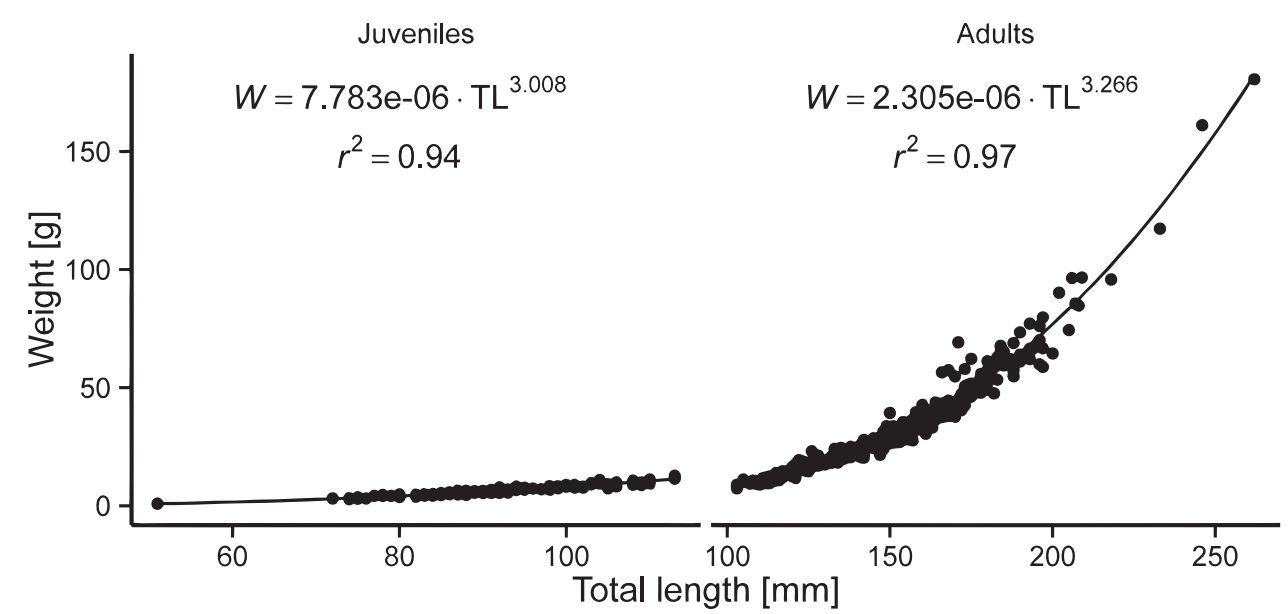

Fig. 4. Length-weight relations for red gurnard, Chelidonichthys cuculus, from the Adriatic Sea: non-linear regression plots for females (left; $n=131$ ) and males (right; $n=166$ ), respectively

Table 3

Percentage of specimens of red gurnard, Chelidonichthys cuculus, from the Adriatic Sea in individual stages of gonad maturity, in relation to the total length (MEDITS surveys 2007-2009)

\begin{tabular}{|c|c|c|c|c|c|c|c|c|c|c|c|c|c|c|}
\hline \multirow{2}{*}{$\mathrm{TL}[\mathrm{mm}]$} & \multicolumn{7}{|c|}{ Maturity stage (females) } & \multicolumn{7}{|c|}{ Maturity stage (males) } \\
\hline & 1 & $2 \mathrm{~A}$ & $2 \mathrm{~B}$ & $2 \mathrm{C}$ & 3 & $4 \mathrm{~A}$ & $4 \mathrm{~B}$ & 1 & $2 \mathrm{~A}$ & $2 \mathrm{~B}$ & $2 \mathrm{C}$ & 3 & $4 \mathrm{~A}$ & $4 \mathrm{~B}$ \\
\hline $90-110$ & 67 & 33 & - & - & - & - & - & 25 & 75 & - & - & - & - & - \\
\hline $110-130$ & 8 & 85 & 7 & - & - & - & - & 8 & 53 & 20 & 17 & - & 2 & - \\
\hline $130-150$ & - & 19 & 50 & 12 & 4 & 11 & 4 & 3 & 3 & 22 & 40 & 15 & 17 & - \\
\hline $150-170$ & - & - & 18 & 21 & 37 & 8 & 16 & - & - & 23 & 40 & 15 & 8 & 13 \\
\hline $170-190$ & - & - & 9 & 9 & 76 & 3 & 3 & - & - & 5 & 21 & 63 & 11 & \\
\hline $190-210$ & - & - & - & - & 8 & 69 & 23 & - & - & - & - & 20 & - & 80 \\
\hline $210-230$ & - & - & - & - & 100 & - & - & - & - & - & - & - & - & - \\
\hline $230-250$ & - & - & - & 100 & - & - & - & - & - & - & - & - & - & 100 \\
\hline $250-270$ & - & - & - & - & - & - & 100 & - & - & - & - & - & - & - \\
\hline
\end{tabular}

In the length ranges the start point is exclusive and the end point inclusive; $\mathrm{TL}=$ total length; Maturity stages (Relini et al. 2008): 1 = immature-virgin, $2 \mathrm{~A}=$ virgin-developing, $2 \mathrm{~B}=$ recovering, $2 \mathrm{C}=$ maturing, $3=$ mature/spawner, $4 \mathrm{~A}=$ spent, $4 \mathrm{~B}=$ resting. 
Trophic spectrum of red gurnard, Chelidonichthys cuculus

(from the Adriatic Sea (MEDITS surveys 2007-2009)

\begin{tabular}{lcccc}
\hline Prey taxon & $\% N$ & $\% W$ & $\% F$ & $\%$ IRI \\
\hline Arthropoda: Crustacea & 93.88 & 91.15 & 76.92 & 98.07 \\
Lophogaster typicus & 82.54 & 69.44 & 37.95 & 97.75 \\
Goneplax rhomboides & 7.69 & 5.27 & 7.44 & 1.63 \\
Solenocera membranacea & 1.46 & 7 & 1.79 & 0.26 \\
Liocarcinus sp. & 1.87 & 2.04 & 2.05 & 0.14 \\
Alpheus glaber & 1.25 & 2.04 & 1.54 & 0.09 \\
Chlorotocus crassicornis & 0.62 & 1.76 & 0.51 & 0.02 \\
Galathea sp. & 1.04 & 0.44 & 0.77 & 0.02 \\
Liocarcinus depurator & 1.04 & 2.52 & 0.26 & 0.02 \\
Ebalia sp. & 0.42 & 0.52 & 0.51 & 0.01 \\
Plesionika sp. & 0.42 & 0.28 & 0.51 & 0.01 \\
Pirimela denticulata & 0.21 & 1.07 & 0.26 & 0.01 \\
Philocheras trispinosus & 0.21 & 0.76 & 0.26 & $<0.01$ \\
Macropipus tuberculatus & 0.21 & 0.76 & 0.26 & $<0.01$ \\
Liocarcinus corrugatus & 0.21 & 0.24 & 0.26 & $<0.01$ \\
Galathea intermedia & 0.21 & 0.02 & 0.26 & $<0.01$ \\
Chordata: Actinopterygii & 1 & 3.38 & 1.79 & 0.05 \\
Callionymus sp. & 0.42 & 5.41 & 0.51 & 0.05 \\
Echinodermata & 0.3 & 0.28 & 0.77 & $<0.01$ \\
Cidaris cidaris & 0.21 & 0.8 & 0.3 & 1.54 \\
Mollusca & 4.02 & 4.89 & 30.26 & 0.01 \\
Unidentified remains & & & 1.86 \\
\hline
\end{tabular}

$\% N=$ numeric prey abundance $[\%], \% W=$ wet weight prey abundance [\%], $\% F=$ frequency of occurrence $[\%]$, $\% \mathrm{IRI}=$ index of relative importance $[\%]$.

understand the abiotic and biotic factors controlling the distribution of red gurnard relating to area.

A positive allometric growth with similar length-weight relations for males and females, was demonstrated by Papaconstantinou (1983), Baron (1985a), Anonymous (2006), Marriott (2010), and by the presently reported study. However, Olim and Borges (2004) found differences in the $b$ values for males and females. In relation to the size classes, the adult individuals showed a steeper slope of the regression indicating a higher growth rate. This greater variability in the length-weight relation depends on many factors that affect the weight of adults such as maturation of gonads or change of diet (Froese 2006).

Red gurnard females reached maturity at greater size than males, in the Atlantic Ocean (Baie de Douarnenez, Brittany, $48^{\circ} \mathrm{N}$-Baron et al. 1985b; North West Wales, $53^{\circ} \mathrm{N}$-Marriott et al. 2010) and in the Mediterranean Sea (Central Tyrrhenian Sea, $43^{\circ} \mathrm{N}$-Colloca et al. 2003). As for the size at maturity, our data are comparable to those reported in the literature being related to the latitude (Vallisneri et al. 2012). The differences can be attributed to environmental changes (particularly temperature that stimulate sexual maturation), such as the photoperiod and prey availability, in addition to internal physiological factors.

Red gurnard, Chelidonichthys cuculus, feed mainly on Crustacea (mostly Lophogastrida) and less on Decapoda, according to many published reports (Colloca et al. 1994 for the Tyrrhenian Sea, Terrats et al. 2000 for the Aegean Sea). However Labarta (1976) noted Decapoda as the main food item of red gurnard off the Spanish coast of the Atlantic Ocean, while Mysidacea (including Lophogastrida and Mysida) were found to be of minor importance. Feeding habits did not change when the fish approached the size of sexual maturity although individuals showed a bathymetrical pattern linked to growth. Our data were in agreement with Colloca et al. (2010) that described red gurnard prey mostly on the lophogastrid, Lophogaster typicus, showing a specialist trophic behaviour overlapping in both food and depth preferences. Our data did not agree with the ones reported by MorenoAmich (1992): around size of sexual maturity, Decapoda increased in respect to Mysidacea and fish represented the most important prey after the crustaceans.

Further investigations are needed to progress on stocks boundaries such as population studies and next management regulations. Overall official catch statistics reported to ICES have shown a decreasing trend over the period 2001-2010 from 6500 to 4000 t, however, there is currently no technical measure specifically applied to red gurnard or other gurnard species (Anonymous 2012).

In conclusion, this study contributes to the general knowledge of a poorly known population biology and environmental of red gurnard in north-eastern Mediterranean. 


\section{ACKNOWLEDGEMENTS}

Sampling was funded through MEDITS and GRUND projects. We thank Professor Corrado Piccinetti for his assistance in bottom trawl surveys and for his valuable suggestions.

\section{REFERENCES}

Anonymous 2006. Report of the working group on the assessment of new MoU species, (WGNEW), 13-15 December 2005, ICES Headquarters, ICES Advisory Committee on Fisheries Management, CM2006/ACFM 11.

Anonymous 2012. Report of the Working Group on Assessment of New MoU Species. (WGNEW), 5-9 March 2012, ICES CM 2012/ACOM 20.

Anonymous 2014. R: A language and environment for statistical computing. R Foundation for Statistical Computing, Vienna, Austria. http://www.R-project.org

Baron J. 1985a. Les triglides (Téléostéens, Scorpaeniformes) de la baie de Douarnenez. I. La croissance de Eutrigla gurnardus, Trigla lucerna, Trigloporus lastoviza et Aspitrigla cuculus. Cybium 9 (2): 127-144.

Baron J. 1985b. Les triglides (Téléostéens, Scorpaeniformes) de la baie de Douarnenez. II. La reproduction de: Eutrigla gurnardus, Trigla lucerna, Trigloporus lastoviza et Aspitrigla cuculus. Cybium 9 (3): 255-281.

Bhattacharya C.G. 1967. A simple method of resolution of a distribution into Gaussian components. Biometrics 23 (1): 115-135. DOI: $10.2307 / 2528285$

Bertrand J.A., Gil De Sola L., Papaconstantinou C., Relini G., Souplet A. 2002. The general specification of the MEDITS surveys. Scientia Marina 66 (Suppl. 2): 9-17. DOI: 10.3989/scimar.2002.66s29

Colloca F., Ardizzone G.D., Gravina M.F. 1994. Trophic ecology of gurnards (Pisces: Triglidae) in the Central Mediterranean Sea. Marine Life 4 (2): 45-57.

Colloca F., Cardinale M., Marcello A., Ardizzone G.D. 2003. Tracing the life history of red gurnard (Aspitrigla cuculus) using validated otolith annual rings. Journal of Applied Ichthyology 19 (1): 1-9. DOI: 10.1046/j.1439-0426. 2003.00342.x

Colloca F., Carpentieri P., Balestri E., Ardizzone G. 2010. Food resource partitioning in a Mediterranean demersal fish assemblage: the effect of body size and niche width. Marine Biology 157 (3): 565-574. DOI: 10.1007/s00227-009-1342-7

Cortés E. 1997. A critical review of methods of studying fish feeding based on analysis of stomach contents: application to elasmobranch fishes. Canadian Journal of Fisheries and Aquatic Sciences 54 (3): 726-738. DOI: 10.1139/f96-316

Coull K.A., Jermyn A.S., Newton A.W., Henderson G.I., Hall W.B. 1989. Length/weight relationships for 88 species of fish encountered in the North East Atlantic. Scottish Fisheries Research Report No. 43.

Dieuzeide R., Novella M., Rolland J. 1955. Catalogue des poissons des cotes algériennes. Bulletin des travaux publiés par la Station d'aquiculture et de Pêche de Castiglione 3: 266-283.

Fiorentini L., Dremière P.-Y, Leonori I., Sala A., Palumbo V. 1999. Efficiency of the bottom trawl used for the Mediterranean international trawl survey (MEDITS).
Aquatic Living Resources 12 (3): 187-205. DOI: 10.1016/S0990-7440(00)88470-3

Forest A. (coordinator) 2001. Ressources halieutiques hors quotas du Nord Est Atlantique: bilan des connaissances et analyse de scénarios d'évolution de la gestion. Contrat IFREMER/MAPA-Ref.99-I1-03-01. Rapport final.

Froese R. 2006. Cube law, condition factor and weight-length relationships: history, meta-analysis and recommendations. Journal of Applied Ichthyology 22 (4): 241-253. DOI: $10.1111 /$ j.1439-0426.2006.00805.x

Froese R., Pauly D. (eds.) 2014. FishBase. [version 06/2014] http://www.fishbase.org

Labarta E. 1976. Aportación al estudio del régimen alimentario y competencia interespecífica de Aspitrigla cuculus, Trisopterus luscus y Trisopterus minutus, de las costas de Galicia. Investigación Pesquera 40 (2): 341-354.

Kallianiotis A., Sophronides K., Vidoris P., Tselepides A. 2000. Demersal fish and megafaunal assemblages on the Cretan continental shelf and slope (NE Mediterranean): seasonal variation in species density, biomass and diversity. Progress in Oceanography 46 (2-4): 429-455. DOI: 10.1016/S0079-6611(00)00028-8

Marriott A.L., Latchford J.W., McCarthy I.D. 2010. Population biology of the red gurnard (Aspitrigla cuculus L.; Triglidae) in the inshore waters of Eastern Anglesey and Northwest Wales. Journal of Applied Ichthyology 26 (4): 504-512. DOI: 10.1111/j.1439-0426.2010.01455.x

Maisan R., Ungaro N., Marzano M.C., Martino M. 1998. Accrescimento di Aspitrigla cuculus (Osteichthyes, Triglidae) nell'area adriatica sub-occidentale: risultati preliminari.

[Growth of Aspitrigla cuculus (Osteichthyes, Triglidae) in the south-western Adriatic area: preliminary results.] Biologia Marina Mediterranea 5 (1): 694-696. [In Italian.]

Massutí E., Reñones O. 2005. Demersal resource assemblages in the trawl fishing grounds off the Balearic Islands (western Mediterranean). Scientia Marina 69 (1): 167-181. DOI: 10.3989/scimar.2005.69n1

Mendes B., Fonseca P., Campos A. 2004. Weight-length relationships for 46 fish species of the Portuguese west coast. Journal of Applied Ichthyology 20 (5): 355-361. DOI: $10.1111 /$ j.1439-0426.2004.00559.x

Moreno-Amich R. 1992. Feeding habits of red gurnard, Aspitrigla cuculus (L. 1758) (Scorpaeniformes, Triglidae), along the Catalan coast (northwestern Mediterranean). Hydrobiologia 228 (3): 175-184. DOI: 10.1007/BF00006584

Olim S., Borges T.C. 2004. Weight-length relationships for eight species of the family Triglidae discarded on the south coast of Portugal. Journal of Applied Ichthyology 22 (4): 257-259. DOI: 10.1111/j.1439-0426.2006.00644.x

Papaconstantinou C. 1983. Observations on the ecology of gurnards (Pisces: Triglidae) of the Greek seas. Cybium 7 (4): 71-88.

Pinkas L.M., Oliphant S., Iverson I.L.K. 1971. Food habits of albacore, bluefin tuna and bonito in California waters. California Fish and Game 152: 1-105.

Ramsay K., Kaiser M.J., Hughes R.N. 1998. Responses of benthic scavengers to fishing disturbance by towed gears in 
different habitats. Journal of Experimental Marine Biology and Ecology 224 (1): 73-89. DOI: 10.1016/S00220981(97)00170-6

Rees E.I.S. 2004. Subtidal sediment biotopes in Red Wharf and Conwy Bays, North Wales: A review of their composition, distribution and ecology. Countryside Council for Wales Contract Science Report No. 655.

Relini G., Carpentieri P., Murenu M. (eds.) 2008. Manuale di Istruzioni Medits. [Medits Instruction Manual]. Biologia Marina Mediterranea 15 (Suppl. 2): 1-78. [In Italian.]

Richards W.J., Saksena V.P. 1990. Triglidae. Pp. 680-684. In: Quero J.C., Hureau J.C., Karrer C., Post A., Saldanha L. (eds.) Check-list of the fishes of the eastern tropical Atlantic (CLOFETA). Vol. 2. JNICT, Lisbon; SEI, Paris; and UNESCO, Paris.

Serena F., Baino R., Voliani A. 1990. Distribuzione dei Triglidi (Osteichthyes, Scorpaeniformes) nell'Alto Tirreno. [Distibution of Triglidae (Osteichthyes, Scorpaeniformes) from north Tyrrenhyan Sea.] Oebalia Suppl. 16 (1): 269-278. [In Italian.]

Terrats A., Petrakis G., Papaconstantinou C. 2000. Feeding habits of Aspitrigla cuculus (L., 1758) (red gurnard), Lepidotrigla cavillone (Lac., 1802) (large scale gurnard) and Trigloporus lastoviza (Brunn., 1768) (rock gurnard) around Cyclades and Dodecanese Islands (E. Mediterranean). Mediterranean Marine Science 1 (1): 91-104. DOI: $10.12681 / \mathrm{mms} .280$
Tsikliras A., Antonopoulou E., Stergiou K. 2010. Spawning period of Mediterranean marine fishes. Reviews in Fish Biology and Fisheries 20 (4): 499-538. DOI: 10.1007/s11160-010-9158-6

Tsimenides N., Machias A., Kallianiotis A. 1992. Distribution patterns of triglids (Pisces: Triglidae) on the Cretan shelf (Greece), and their interspecific associations. Fisheries Research 15 (1-2): 83-103. DOI: 10.1016/01657836(92)90006-F

Vallisneri M., Montanini S., Stagioni M. 2010. Length-weight relationships for the family Triglidae in the Adriatic Sea, northeastern Mediterranean. Journal of Applied Ichthyology 26 (3): 460-462. DOI: 10.1111/j.1439-0426.2009.01389.x

Vallisneri M., Montanini S., Stagioni M. 2012. Size at maturity of triglid fishes in the Adriatic Sea, northeastern Mediterranean. Journal of Applied Ichthyology 28 (1): 123-125. DOI: 10.1111/j.1439-0426.2011.01777.x

Wheeler A. 1969. The fishes of the British Isles and North-West Europe. Macmillan, London, UK.

Zuur A.F., Ieno E.N., Elphick C.S. 2010. A protocol for data exploration to avoid common statistical problems. Methods in Ecology and Evolution 1 (1): 3-14. DOI: 10.1111/j.2041210X.2009.00001.x

Received: 9 December 2013 Accepted: 1 June 2014 Published electronically: 15 October 2014 